\title{
BANKRUPTCY ANALYSIS OF NATIONAL AIRLINES COMPANIES IN REGIONAL ASIA AFTER COVID-19 PANDEMIC
}

\author{
Asaduddin Abdullah ${ }^{* 1}$, Noer Azam Achsani*), and Suhendi*) \\ *) School of Business, IPB University \\ Jl. Pajajaran, Bogor 16151, Indonesia
}

\begin{abstract}
The Corona Virus Disease (COVID-19) was declared a worldwide pandemic by the World Health Organization (WHO) on March 11, 2020. The main pandemic countermeasure with physical distancing and limitation to travel heavily damaged the airline industry around the world, which slumps the direct revenue to the company. Hence, the industry should utilize this tight cash flow and the volatility business due to high operating costs and the high cost of labor. This situation could be worsening to the various national carrier in Asia already performs poorly far before COVID-19. Therefore, this research will predict the bankruptcy of four national airline companies in regional Asia using a modified version of Altman Z Score and Zmijewski Model. This research will show the current and future condition of financial performance in each company. Those National Airlines, namely PT Garuda Indonesia Tbk. (IHSG: GIAA), Singapore Airlines Ltd. (SGX: CL6), Thai Airways International (BKK: THAI), and Eva Air (TPE:2618). This study's results indicate financial distress and possibly to be bankrupt for two national airlines company, especially in Garuda Indonesia and Thai Airways, compared to other selected national airlines. Thus, those financial distress companies should carefully allocate remaining assets, liquidate the unproductive entities, and perform a company reconstruction to avoid bankruptcy in the future.
\end{abstract}

Keywords: covid-19, bankruptcy analysis, regional airlines industry, modified altman $\mathrm{z}$-score, financial distress

\begin{abstract}
Abstrak: Penyakit Virus Corona (COVID-19) dinyatakan sebagai global pandemi oleh Organisasi Kesehatan Dunia (WHO) pada 11 Maret 2020. Penanggulangan untuk meredam penyebaran pandemi dengan mematuhi protokol kesehatan yaitu menjaga jarak fisik dan pembatasan perjalanan ke daerah lain telah menimbulkan dampak yang cukup parah bagi industri penerbangan di seluruh dunia. Industri penerbangan harus memanfaatkan dengan ketat arus kas yang tersisa dan kondisi bisnis yang tidak stabil karena tingginya biaya operasional dan biaya tenaga kerja. Situasi pandemi ini memperburuk kondisi finansial berbagai maskapai nasional di regional Asia yang sudah berkinerja buruk jauh sebelum adanya pandemi COVID-19. Oleh karena itu, penelitian ini akan memprediksi kebangkrutan empat maskapai penerbangan nasional di kawasan Asia dengan menggunakan Altman Z Score yang dimodifikasi dan Zmijewski Model. Penelitian ini akan menunjukkan kondisi kinerja keuangan masing-masing perusahaan saat sebelum pandemi dan di masa yang akan datang. Perusahan penerbangan regional Asia yang diteliti adalah PT Garuda Indonesia Tbk. (IHSG: GIAA), Singapore Airlines Ltd. (SGX: CL6), Thai Airways International (BKK: THAI), dan Eva Air (TPE: 2618). Hasil penelitian menunjukkan adanya indikasi kesulitan keuangan dan kemungkinan bangkrut bagi dua maskapai penerbangan nasional, khususnya Garuda Indonesia dan Thai Airways, dibandingkan maskapai nasional terpilih lainnya. Maka dari itu, untuk perusahaan yang mengalami kesulitan keuangan dan berpotensi untuk bangkrut sebaiknya cermat dalam mengalokasikan sisa aset perusahaan, melikuidasi entitas anak yang tidak produktif, dan melakukan rekonstruksi internal perusahaan untuk menghindari kebangkrutan di kemudian hari
\end{abstract}

Kata kunci: covid-19, analisis kebangkrutan, industri penerbangan regional, modifikasi altman z-score, kesulitan keuangan

${ }^{1}$ Corresponding author:

Email: asaduddin.abdullah@gmail.com 


\section{INTRODUCTION}

Since the World Health Organization (WHO) announced the (Corona Virus Disease) COVID-19 outbreak as a global pandemic on March 11, 2020, our lives had been overturned. Economic activities have disrupted around the world people around the world forces to obey the physical distance protocol. The virus identified as of April 9, 2020, the COVID-19 outbreak, originated in a wet market in Wuhan, Hubei Province, China. And within one month has reached 203 countries, confirmed affecting 1.476 .819 persons, with more than 87.816 deaths by April 30, 2020, and this confirmed data still risen day by day. In ASEAN, the numbers are increasing exponentially, with more than 15,532 confirmed cases and more than 529 deaths reported by April 30, 2020. All ten ASEAN Member States have confirmed cases, and the number of expected infections is feared to increase manifolds in the coming days. Undoubtedly, the coronavirus has a negative impact on the South East Asian economy and the rest of the world at the beginning of 2020. the primary sectors have been affected, particularly travel and tourism, retail, and other human-services sectors. Besides, supply chains are disrupted; employment and health sectors put at risk, while consumer confidence has declined. The COVID-19 outbreak also has diminished prospects of economic recovery from a broad global that has already slowed down last year.

Furthermore, the first case of COVID-19 was detected in Indonesia on March 2, 2020, and at least a week, the virus increased more than 12,776 confirmed cases, and 930 deaths had been reported in all 34 provinces. However, modeling studies estimate that as few as 2 percent of all infections have been reported (Rustikno, 2020). With no treatment or vaccine available, Indonesia and other developing countries are heavily-relying on large scale-physical distancing to slow down the human to human spread of the virus. Government interventions being implemented in Indonesia include: quarantine of those infected in, restrictions on domestic movement and international travel, bans on group activities and crowd gatherings, high level of people movement restriction (PSBB) in big cities, and the closure of schools, factories, restaurants, and public spaces. This virus preventive-intervention by the Government lead a direct impact on economic activities.

Indonesia has experienced high growth rates of GDP with approximately 5 percent for the past decade but has slashed the forecast in 2020 to around 2 percent by BPS (2020). The measures taken to contain the COVID-19 have dealt a devastating blow to the Indonesia economy. A worst-case scenario by IMF (International Monetary Fund) forecasts an even more dramatic fall with minus 3.5 percent in 2020. Equally, global economic growth is expected to see a negative increase of minus 3 to 4 percent in 2020. This situation is called "double curve" - with the confirmed curves that were going up and recession curves going down. Both curves need to be mitigated and flattened to reduce the confirmed cases and simultaneously reduce the downdrawn economy by correctly balancing public health and economic growth.

Moreover, the coronavirus pandemic involves both supply and demand shocks. The business disruptions have lowered production while creating shocks to supply. Which caused hesitation from buyers to spend more and lowered demand. On the other hand, there is a direct reduction in economic activity from the supply side because of efforts to limit the spread of the disease through the large scale of lockdowns and limitation of people's movements to another city. This situation leads to a massive drop in the supply capacity and tourism sectors (Gilbertson, 2020). Besides, many airlines industry that relies on people's movement around the globe may be unable to get a limit number of passengers they need to fly, whether domestically or internationally, leading to many airplanes grounded and re-scheduling the profitable routes. Together, these pandemic disruptions contribute to a rise in business costs and constitute a negative operation shock, reducing economic activity and ultimately will lead the bankruptcy to National Airlines Industry and airlines related industry.

On the demand side, the loss of staple jobs, fear of contagion of the virus, and leading the uncertainty, this will make people spend less. Business tightened the cash flow, and workers may be laid off, as firms are unable to pay their salaries. These effects will also lead people to postpone the planned vacation and directly impact the tourism and hospitality sectors. Since the start of the year 2020, the U.S. equity market starts to sell off from February 20 2020, and airline stock prices have been hit, also on the bearish condition, this condition similar to the post-9/11 terrorist attacks and SARS pandemic but lower than after the global financial crisis in 2008. In addition to these sectoral effects, worsening consumer and business confidence can lead the firms 
to expect lower demand and reduce their planned spending and investment. In turn, this would worsen airline business closures and fill bankruptcy forms.

The Airline Industry's growth in Asia region can also be marked by seeing their achievement year by year. SKYTRAX, one of the prestigious airline awards since 1989, announces Asia Airlines dominates the best airlines in the world for the last consecutive five years. Singapore Airlines was awarded the best airline in the world 2018, followed by Qatar Airways, ANA, Emirates, EVA Air, Cathay Pacific, Lufthansa, Hainan Airlines, Garuda Indonesia, and Thai Airways, respectively.

However, no matter how many awards they brought, there is no guarantee that the airlines would be financially stable. Through the promising growth of the airline industry, this industry remains an unstable industry compared to others. The operational cost is raising such fuel and labor that affects its margin in operation. The fluctuating oil and jet fuel prices, high fixed and variable costs, market price, are the main reason why this industry considered highly volatile (Airline Industry Outlook, 2018). Even in 2017, almost all Airlines Industry in Southeast Asia is underperformed (Centre for Aviation, 2019).

Most Southeast Asia airlines experienced the decline these past years, especially Indonesia's national carriers, Garuda Indonesia, which also the biggest Airline in Indonesia. The growth of the aviation industry and Indonesia's economic condition does not make Garuda Indonesia show positive financial performance, their financial condition reported to a loss for these past years. Based on the data presented of their Garuda Indonesia annual report in 2017, Garuda Indonesia hides a substantial net loss in 2017 (Schofield, 2018). Indonesia's Government concerns the overall performance of the biggest airline company in Indonesia, which is also one of the Indonesian StateOwned Company.

Moreover, other airlines industry in Regional Asia also reported loss. In March 2019, Singapore Airlines declared a loss of 138 million SGD (CNA, 2019). And at the same time, Thai Airways, as the Best Airlines in Economic Class in the world, also suffered 3.69 billion THB loss in their third-quarter 2019 (CNA, 2019). This situation is getting worse by the pandemic of COVID-19, which halted any activities that involved human movement. The airline and tourism sector is the worst industry that affected this downturn in the economy.

Thus, this research will predict the bankruptcy of four national airline companies in regional asia using "Altman Z"-Score. This research will show the current and future condition of financial performance in each company based on their bankruptcy score and also the stock performance mainly on Garuda Indonesia (GIAA) as Indonesian National Carrier. There are four top Airlines in Regional Asia to be included in this study, respectively Garuda Indonesia (GIAA), Singapore Airlines (SING), EVA Air (EVA), and Thai Airways (THAI). They are formed as group and holdings companies which considered to have other subsidiaries and entities under the main company. Due to the same level of airline companies, they visible to be compared to each other. Moreover, this research is focused on the GIAA due to the bad financial performances reported for the past five years and possible solutions to GIAA stakeholders and the Indonesian Government to overcome this difficult situation.

There are several authors that investigate the interaction between pandemics and economic impact and dynamics by theoretical modeling by Eichenbaum et al. (2020). Their model proposes that containment policies that promote reductions in consumption and work can reduce the number of deaths attributed that caused by the pandemic. These policies, perversely, will bring negatively impact the economy and worsen the effects of the subsequent recession. As the spread of COVID-19 continues, the expected reduction in consumption is realized as jobless claims reach nearly 10 million in March 2020 (Duan, 2020; Wolfers, 2020). There is another study, Barro et al. (2020), that uses the Spanish flu and WWI deaths as representatives to quantify the economic impacts a nation could expect during a pandemic. Their analysis estimates that a country on average will experience an $8 \%$ decline in GDP and a $6 \%$ decline in consumption. Barro et al. (2020) also discover an increased stock market and interest rate volatility during these pandemic periods. Their work implies that situations similar to the current COVID-19 panic can result in financial conditions like the Great Recession in upcoming years. Atkeson (2020) remarks that models of the spread of COVID-19 suggest that social distancing and the associated economic tradeoffs could last for nearly 18 months after the outbreak. Additionally, McKibbin and Fernando (2020) use data from China, the pandemic epicenter, to model the 
potential impacts of the COVID-19 spread. They find rough estimates of a $1 \%-5 \%$ shock to consumption and an equity risk premium shock of $1.07 \%$.

In history, the airline industry has been threatened by global crises that directly affect the revenue. From the oil embargo in 1970s, airline deregulation in 1990s, terrorist attacks in $2000 \mathrm{~s}$, the industry has experienced many disturbances (Davies, 2016). The survival of an airline industry during and after this turbulence is often related to the adaptive airline's business model. There is Franke and John (2011) state that the attacks on WTC 9/11 caused a significant reduction in air travel passengers, and airlines struggled to maintain their business. Further, as the spread of SARS, demand was only restored to the year 2001 levels by the end of 2004 (Franke and John, 2011). Through this period, low-cost carriers (LCC) achieved a larger market share as major air carriers struggled to overcome as pricing competition increased (Tan, 2016). Moreover, rising fuel prices also prevented the recovery of the industry following 2011. Major airlines adjusted the capacity to compensate for this increased cost leaving LCC airlines opportunities to enter new markets (Sibdari et al., 2018). Besides, the sub-prime mortgage recession in 2008 has further changed the network and routing structure of airlines in tourism-based hubs, as they attempt to mitigate the impacts of the decline in demand by cutting capacity (Pearce, 2012).

Financial Distress or business failure is defined as the inability of a firm to pay its financial obligations as they mature (Zopounidis, 1996). Also, failures are when the company cannot pay its suppliers, shareholders, or lenders (Altman, 1968). Business failure is a part of bankruptcy, which is defined as the state of being entirely lacking in a particular quality to remain competitive. Furthermore, a Bankruptcy Prediction stands for a prediction towards the failure of a company in the future. Bankruptcy Prediction is varied from the number of an attribute to be considered. This one is of the most popular models is the Altman's 1968 model with its five factors multivariate discriminant analysis model (Altman, 1968).

Every company management recognizes the state of being financially distressed, and shareholders tend to very concerned about this situation (Yuliastary, 2014). Financial distress conditions need to be known early so that management can determine possible actions to anticipate the bankruptcy (Haryetti, 2010). The financial distress calculation model has been around for the past five decades and is useful for predicting corporate financial problems. The calculation model is usually taken from the financial statements: solvency ratio, activity, profitability, investment, and leverage. (Sarlija and Jeger, 2011). Fi mnancial distress does not only occur because of the company's internal impact. However, there are impacts from the external condition, such as the macroeconomic economy. Thus, the ends of bankruptcy can cause massive effects for shareholders, investors, creditors, managers and its employees (Salehi and Abendini, 2009).

According to the Hanafi and Halim (2007), the financial analysis of bankruptcy is intended to obtain early warning signs of bankruptcy. The earlier signs of the bankruptcy discovered, the better the management as management can make improvements and perform to outcome the situation (Khan, 2014). Moreover, the shareholders can make preparations to cope with the worse possibility of adjusting their portfolio. Thus, in this study, the signs of bankruptcy are investigated using the companies financial report data. In practical and also in empirical research, financial distress is difficult to define. That of kind difficulties could mean the start from a cash liquidity problem in the shortterm, which is the lightest financial difficulties, up to the declaration of bankruptcy, which are the most severe difficulties. Thus financial difficulties can be seen as great difficulty, ranging from the mild to the most critical.

There are several authors that investigate the bankruptcy model such as; study by Kumar and Anand (2013) used The Altman's Revised Z-Score Model also used and assessed by to predict the Bankruptcy of Kingfisher Airlines in India. The other service company also uses Altman's Revised Z-Score Model to predict the Bankruptcy of the Shipping Service Company in Indonesia (Manalu, Octavianus, and Kalmadara, 2019). Several authors have investigated the bankruptcy prediction study in Indonesia. Kuncoro (2012) examined the bankruptcy of PT Betonjaya Manunggal Tbk from 2007 till 2012 used Springate and Zmijewski model, which both model give us the same conclusion PT Betonjaya Manungga Tbk was not in a bankrupt state.

Another study related to the bankruptcy model from Fakoano (2018), the study was to analyze PWON financial distress using the Zmijewski calculation, and 
its relations to other independent variables. The results show exchange rates, interest rates, operating expenses growth, COGS growth, and DER have a long-term and short-term effect on Zmijewski's value. Further, Adnan and Arisudhana (2011) researched company bankruptcy used Z-Score and Springate model in the property company. And the Z-Score model gives a different conclusion with the Springate model since 2005-2009 at the property company. Additionally, Peter and Yoseph (2011) also conducted bankruptcy prediction research using three models, namely Z-Score, Zmijewski, and Springate to PT Indofood Sukses Makmur Tbk period 2005-2009. There are results between the three model prediction, the Z-Score model with Zmijewski model gives a contradictive result.

There is various research conduct research about bankruptcy prediction. However, most of them not included the event caused economic downfall. Thus in our paper, we investigate the pandemic shock impact on those national airlines company and predicting the financial distress state. Moreover, in this study, we try to fill the research gaps and provide a slight difference reference for the study between the pandemic caused impact on the economic downturn and its effect on the national carrier, particularly the national-owned airline industry in regional Asia.

\section{METHODS}

In this research, the data used that we used are quantitative data from selected four regional airline companies - the quantitative data considered as numerical data, which derived from the financial report of the company. The data are collected from the quarterly report of each company listed and appeared on their official website. The data were taken from the financial report published quarterly from the first quarter of 2018 until the first quarter of 2020, with a total of 36 financial reports from four airlines company. Those airlines companies consist of Garuda Indonesia (IHSG: GIAA), Singapore Airlines Ltd. (SGX: CL6), Thai Airways International (BKK: THAI), and Eva Air of Taiwan (TPE:2618). Futher, the analytical tools used for this study were Altman Z-score and Zwijewski. and the Excel and SPSS were the software used to assist in the analysis of the study.

\section{The Altman Z-Score}

Altman developed the first model is the five-factor model to predict the bankruptcy of the manufacturing company, which are chosen based on their best doing in the overall job together while predicting corporate bankruptcy (Auchterlonie, D. 1997). Altman Z Score is a financial analysis model for identifying corporate financial performance related to the potential of bankruptcy (Auchterlonie, D. 1997). The model has been updated since 1984 to adapt to the economic condition in several countries, such as Japan, Australia, Netherlands, and many other countries, due to that issues, this Altman Model is a model that accepted globally (Sedgwick, P. 2012).

This model named" Z-Score", Altman Z-Score has a varied percentage of accuracy for every sample, which are $95 \%$ accuracy for one year before bankruptcy, $70 \%$ for two years before bankruptcy, $48 \%, 29 \%$, and $36 \%$, respectively for three, four, and five years before it happens. Those factors are grouped into five standards ratio, which are profitability, leverage, liquidity, solvency, and activity ratios.

The first form of the Altman's Z-Score is:

$$
\begin{aligned}
\mathrm{Z}= & 0.012(\mathrm{X} 1)+0.014(\mathrm{X} 2)+0.033(\mathrm{X} 3)+0.006(\mathrm{X} 4) \\
& +0.999(\mathrm{X} 5)
\end{aligned}
$$

Where: Z (Overall Index (Z-score)); X1 (Working capital/Total assets); X2 (Retained Earnings/Total assets); X3 (Earnings before interest and taxes/Total assets); X4 (Market value equity/Book value of total debt) X5 (Sales/Total assets).

The first formula of Altman's Z-Score has initially been made for predicting the bankruptcy of manufacturing companies. Then, Altman developed the modified Z-Score model to predict the bankruptcy of nonmanufacturing companies such as airline services. The method simply cut out one variable, X5, or total sales (Auchterlonie, 1997). It slightly intends to reduce the effects of the capital turnover ratio. As a result, the developed model of Altman's Z-Score for Nonmanufacturers company is:

$$
Z ”=6.56(X 1)+3.26(X 2)+6.72(X 3)+1.05(X 4)
$$


Where: Z" (Modified Z-Score, overall index); X1 (Working capital/Total assets); X2 (Retained Earnings/ Total assets); X3 (Earnings before interest and taxes/ Total assets); X4 (Market value equity/Book value of total debt).

The development of modified Altman's Z-Score Model is more applicable for the non-manufacturers company, especially in specific industries like airlines, services, retailers, hospitality, etc. The ratios used in this model consists of (Altman and Hotchkiss, E, 2008):

\section{X1 - Working Capital/Total Assets (WC/TA). This ratio} is a calculation of the firm's net liquid assets relative to the total capitalization with Working Capital as the difference between current assets and current liabilities. Liquidity and size characteristics are considered.

X2 - Retained Earnings/Total Assets (RE/TA). Retained earnings are considered the total amount of reinvested earnings and losses of a company and the cumulative profitability over its entire life. Retained Earnings/ Total Assets (RE/TA) primarily measures the leverage of a company. When this ratio indicates the high value, it implies that a company has have not utilized as much debt and more financed its assets through the retention of profits. Moreover, RE/TA Ratio focuses on the use of internally generated funds for growth, which considers as low-risk capital or third party money, which considers higher-risk capital.

X3 - Earnings before Interest and Taxes/Total Assets (EBIT/TA). This ratio calculates the productivity of a firm's assets, detached with any tax or leverage factors. This ratio appears to be applicable for any studies that dealt with credit risk because of a company's essential existence is based on the earning power of its assets.

X4 - Market Value of Equity/Book Value of Total Liabilities (MVE/TL). Equity is the accumulation of market value of all shares of stock (preferred and conventional), and both current and long-term obligations are included in Liabilities. The calculation presents how much the firm's assets can decline in value, measured by the market value of equity plus debt. Before the liabilities overdoes, the assets and the company become unbalanced.

The modified Z-Score of the Airlines Companies in Asia are selected from financial reports 2018, 2019, and the first quarter of 2020 . The data gathered from the quarterly report of the company. The model used is the modified Altman's Z"-Score Model because Airlines Company is considered a non-manufacturing company. The equation of this model will result in the specific values which show their condition in terms of bankruptcy. When the score showed more than 2.67, it means that the company's possibility of bankruptcy is very low and counted in the" safe zone. If the value is in between, $1.1 \geq Z^{\prime \prime} \leq 2.6$, the company will be Bankrupt in the next two years or early warning sign and counted in the "grey zone". Lastly, if the values of $\mathrm{Z} "<1.1$ considered as dangerous or are in the "distress zone" (Altman, 2000). One of the ratios that taken out from the modified version is the sales/total assets ration. A low total numbers assets figure reduces these ratios and results in a lower Z-score, so in this study, we used the modified version. Thus, the model was a linear combination of several independent variables that provided cut-off scores estimating the company's financial health. This condition creates the impression that the company is financially distressed.

Table 1. Altman Z-score Model

\begin{tabular}{cc}
\hline Modified Altman Z-Score & Meaning of the cut-off points \\
\hline$Z>2.67$ & Non-distress Zones \\
$1.1 \geq Z^{\prime \prime} \leq 2.6$ & Grey Zones \\
$Z^{\prime \prime}<1.1$ & Distress Zones \\
\hline
\end{tabular}

The first Altman Z-score was later modified to be able to perform in non-manufacturing industries. For some reason, the first model appears to generate a lot of mixed reception among scholars; some are in support of it while others are opposite it. However, Grice and Ingram (2001) indicated that the model's accuracy is significantly lower in recent periods than reported in Altman's study. Besides, there are several criticisms against the first z-model, such as 1) its overdependence on the financial data. 2) lack of evidence from non-financial ratios. 3) the model focus on failure rather than how to make sustainability of the business. 4) the need for industry-specific or geography-specific model types and the danger of flexible interpretation or manipulation of financial results. 5) the model leading to conduct "window dressing" financial position to looks better returns (Wilkinson, 2009).

One of the main-limitation of Altman Z-score is the requirement for industry-specific or geographyspecific model types. The specific industries have different characteristics; hence it would not be feasible to implement the general (first) model for all 
industries. Another limitation of this Altman $\mathrm{Z}$ model is the presumption that more includes the financial ratios from public financial disclosure. Meanwhile, most of the companies which in financial distress state will manipulate their financial statements to show better financial performance for shareholders. (Panneerselvam, 2008).

\section{The Zmijewski Model}

The bankruptcy model from the Zmijewski (1984) used ratio analysis that measures the performance, leverage, and liquidity of a company used for the model predictions. At first appliance, Zmijewski Model investigated and analyzed and implemented it to the 40 companies that have gone bankrupt, and the rest of 800 companies that still survive at that time and perform outcome the bankruptcy. Zmijewski model estimation criteria are, the greater the value of $\mathrm{X}$, the more likely the company went bankrupt, the model successfully developed as follows:

$$
\mathrm{Zm}=-4.3-4.5(\mathrm{X} 1)+5.7(\mathrm{X} 2)-0.004(\mathrm{X} 3)
$$

Where: ZM (Zmijewski Model, the overall index); X1 (Profit after-tax/total assets); X2 (Total debt/total assets); X3 (Current assets/current liabilities).

\section{Coefficient Correlation}

A correlation coefficient is a statistical estimation of differences between one variable to another variable. A correlation could be identified as the level of association between two variables. However, regression described as a figure of a relationship between particular values of one variable and the propose of corresponding values of the second (Ana \& González, 2006). Generally, correlation aims to know the interdependency, while regression leads to the study of dependency. Other than that, Person Correlation is suitable for parametric data and data with interval and ratio, such as financial ratio, as it used in several empirical studies to identify the correlation between financial ratios. In this research, the Correlation Coefficient will help to examine the relationship between PT. Garuda Indonesia Bankruptcy Prediction Score from Altman Z Score with Bankruptcy Prediction Score from Zmijewski Model.

In this paper, the Coefficient Correlation method used for identifying the interdependency between two variables. This method also can measure the strong relationship between variables. In this research, Coefficient Correlation or Pearson's Correlation is used for identifying the relationship between PT. Garuda Indonesia Altman Z Scoce Bankruptcy Prediction Score with the Zmijewski Model with a 5\% error. Before calculating the coefficient correlation, the data of airline companies that predicted bankrupt should be collected.

Moreover, the data should be normally distributed so that the test statistic will be validated. The normality test will be conducted by One-Sample KolmogorovSmirnov (Field, 2009). Then the data will be calculated by using SPSS Software to identify the relationship correlation. The correlation will be measured by the scale of $-1,0,+1$ Closer to +1 , which means the data has a positive relationship. In contrast, if closer to -1 means that the data has a negative correlation. If the data shows 0 as the correlation score, it means that the data is not correlated. The data also has to have a Significance score of less than 0.05 to correlate with variables. Lastly, in this study, we only investigate the financial ratio of four airlines before COVID-19 and after COVID-19. We are not going further to each subordinate's business entities and look further at any operational cost.

\section{RESULTS}

General information of four national carriers selected in this study show in Table 2. Garuda Indonesia and Singapore Airlines have the longest history, but the net profit between them are hugely different. Even with the almost near the same number of fleet size, Garuda Indonesia could not match with Singapore Airlines. On the other hand, Eva Air, with a relatively new company, could book 218 million net profit. Moreover, looking from the number of employees, Garuda Indonesia and Thai Airways has a large number of employees that counted two times compares to Singapore Airlines and Eva Air. This condition indicates that Garuda Indonesia and Thai airways could not perform efficiently managed their business. And the outbreak could bring the business even worse.

During the COVID-19 pandemic, the airline industry has experienced a decrease in capacity of roughly $60-80 \%$ at major carriers (Josephs, 2020) as demand turmoil causes further reductions by the airline's flight schedule. The unspecified timeline for removing or 
losing social distancing and travel restrictions has increased uncertainty for the industry. In the USA, the Government has passed a massive financial stimulus bill to assist the slow-down airline industry (Gilbertson, 2020). Airport Council International World estimates a reduction of more than two billion passengers globally in the second quarter of 2020. it brings the decline in total airport revenues is expected to reach $\$ 39.2$ billion in the second quarter and more than $\$ 97$ billion for 2020. (ACI, 2020).

The main problem that major national airlines companies will be facing after this pandemic is whether they should leave planes on the ground and keep paying the rent for its hunggar or distribute them to other markets. Both decisions are tough with handling a few planes is expensive since the companies will have to continue paying the rents for airplanes, especially for Garuda Indonesia, with counts more than 60 percent is rented planes. But redeploying them is also disturbing when the other markets are not very dynamic. Another strategy by increasing it capacity can indeed lead to lower prices for filling aircraft, but during the this outbreak always difficult to perform that, with all companies should obeying the health protocol.

If we look back to previous outbreak in 2002, during SARS pandemic the decline in aircraft passenger lasted five to seven weeks from the first confirmed case. There was a recovery state that starting from the tenth to the fifteenth week. Still, the coronavirus impact will be higher than SARS simply because China and Southeast Asia as a market is larger and represents an essential share in the world aviation industry. Also, the virus out passed SARS in terms of deaths and infected people. Many countries fear the outbreak and decided to keep their airports closed and banning people traveling from China, which can retain overseas airlines taking their services out of the systems until the end of April 2020. However, this outbreak does not have only negative impacts but also a positive one for the aviation industry. The news of a drop in demand for oil thus leads the oil price to fall to the historical low. Therefore, a decline in oil prices can be favorable for airline companies considering an oil to be one of the main costs for airlines. Overall, the novel coronavirus will severely affect air travel and the aviation industry in the short run and will significantly impact the world oil industry production. However, it's still too early to say how significant the novel Coronavirus's impact will be.

Throughout nine quarters of financial report studies which apply the modified Altman Z"-Score in four airline companies in regional Asia, it shows the worst period is in the first quarter of 2020. During the first quarter of 2020, all selected airlines showed the Z"Score less than 1.1 and which minus values appeared on Garuda Indonesia and Thai Airways. They are predicted to be bankrupt in the next two or three years in advance if the management does not conduct any financial decision or re-constucture its business.

Table 2. General Information of selected national airlines company compared with Garuda Indonesia

\begin{tabular}{lcccc}
\hline & \multirow{2}{*}{ Garuda Indonesia } & \multicolumn{3}{c}{ Regional Airline Company } \\
\cline { 3 - 5 } & & Thai Airways & Singapore Airlines & Eva Air \\
\hline Year Establishment & 1947 & 1960 & 1947 & 1989 \\
IATA & GA & TG & SQ & BR \\
Hubs City & Jakarta & Bangkok & Singapore & Taipei \\
Fleet Size & 144 & 100 & 137 & 82 \\
Number of Destinations & 91 & 74 & 62 & 62 \\
Operting Revenue (in Million USD, 2019) & 4.572 & 5.939 & 8.212 & 4.526 \\
Net Profit (in Million USD, 2019) & 6 & -378 & 558 & 218 \\
Number of Passenger Carried (Million, 2019) & 31 & 24 & 20 & 12 \\
Passenger Load Factor (\%, 2019) & 74 & 79 & 84 & 81 \\
Number of Employees (2019) & 21.773 & 22.054 & 14.729 & 11.147 \\
\hline
\end{tabular}


While Singapore Airlines experienced a steady performance during the year of 2018 and for beginning 2020, the pandemic caused a sudden impact, which resulted in the $\mathrm{z}$ values in less than 0.87 in the red zone. Singapore Airlines considered the only airlines that include in the study that having a long history of excellent performance with Z"- Score more than 2.6 in the year 2018 until Q2 2019. Particular remark for Garuda Indonesia and Thai Airways that won numerous awards in the past and enjoyed the domestic economic growth but unable to perform better results financially, this condition due to ineffective and inefficient use or all the available asset.

The result in Table 3 showed that the Garuda Indonesia has the lowest Altman Z"-Score compared to others. As Altman Z"-Score also can identify the financial performance, for the past two years, Garuda Indonesia has bad financial returns, which could lead them to go bankrupt for the next two or three years. Beside, Garuda Indonesia experienced the loss for the past five years with several factors and scandals. Jet fuel prices may affect the financial performance of Garuda Indonesia, too, as all of the airlines in the world experienced that, while there may be many other internal reasons why Garuda Indonesia has been going down. In contrast, others still have the chance to perform better.

Those bankruptcy events in Garuda Indonesia and Thai Airways may occur not because of the external factors and global geo-politics conditions that happen surround them. Those external factors include fuel price, global stock prices, currency exchange, fuel price, and many other things, besides the stock price that would depend on the company's performance and influence by the company's internal factors. The economic condition of each company would also be different, as those companies came from different countries. While the fuel price, which remains unstable, also depends on the company's agreement on fuel hedging policy.

Bankruptcy prediction calculation using Zmijewski provided more results were affirming that the company was heading to a healthy-financially company or potentially bankrupt. Bankruptcy Prediction Calculation using Zmijewski model did not have a certain scale in assessing a company when it to be excellent or poor condition different with Altman $\mathrm{Z}$-score, but the value of $\mathrm{Zm}$ (Zmijewski value) can be seen as resulting from an average company in a negative number or small numbers, which means the company can be categorized in good condition. We can perform the correlation test to identify the relationship between the Altman z-score model and Zmijewski Model that is shown in Table 4.

Simple correlation analysis for the Z-Score model and Zmijewski Model was conducted to determine the relationship between the two bankruptcy prediction models shown in Table 4. The conclusion was that the dependent variable relationships were strong, with figures showing the relationship between the two of 0.719 . The relationship between these two predictions was unidirectional because the number is a positive relationship.

Table 3. Airlines Company's modified Altman Z-score result for Q1 2018- Q1 2020

\begin{tabular}{lccccccccc}
\hline \multirow{2}{*}{ Airlines Company } & \multicolumn{4}{c}{2018} & \multicolumn{2}{c}{2019} & \multicolumn{2}{c}{2020} \\
\cline { 2 - 9 } & Q1 & Q2 & Q3 & Q4 & Q1 & Q2 & Q3 & Q4 & Q1 \\
\hline Garuda Indonesia & -1.14 & -1.53 & -1.48 & -1.61 & -1.72 & -1.81 & -1.72 & -1.58 & -2.15 \\
Thai Airways & 0.81 & 0.54 & 0.34 & 0.33 & 0.43 & -0.12 & 0.12 & -0.42 & -1.58 \\
Singapore Airlines & 3.92 & 2.83 & 2.71 & 2.73 & 2.52 & 2.19 & 1.56 & 1.34 & 0.87 \\
Eva Air & 1.32 & 1.76 & 1.12 & 1.02 & 1.01 & 1.29 & 1.51 & 0.98 & 0.05 \\
\hline
\end{tabular}


Tabel 4. Correlation result of Z Score and Zmijewski model

\begin{tabular}{lcc}
\hline & $\begin{array}{c}\text { Modified } \\
\text { Z-Score }\end{array}$ & $\begin{array}{c}\text { Zmijewski } \\
\text { model }\end{array}$ \\
\hline Z Score & & \\
Pearson correlation & 1 & $-0,04$ \\
Significant (2 tailed) & & 0,71 \\
$\mathrm{~N}$ & 36 & 36 \\
Zmijewski & & \\
Pearson correlation & $-0,04$ & 1 \\
Significant (2 tailed) & 0,71 & \\
$\mathrm{~N}$ & 36 & 36 \\
\hline
\end{tabular}

National Airlines are among the worst affected sectors and would do not seem to recover anytime soon. Singapore Airlines and Thai Airways are expecting revenues to fall $90 \%$ in the Second Quater of 2020 (World Aviation, 2020). Apart from that, the decreased number of passengers that will directly impact on revenue loss. Besides paying for parking approximately more than $\$ 1000$ a month for a large plane in Indonesia, keeping idle airplanes requires periodic maintenance that accounts for sizeable costs. For instance, hydraulics \& flight-control systems require protection against wildlife, and engines should be turned on at intervals of times. Moreover, humidity can corrode parts for which exterior parts. Unlike a car, airplanes are complex pieces of machinery that will require a dozen of money to keep them on well-maintained conditions. When the beginning of the pandemic, which fear-sentiments are bombarded the oil prices hit the lowest price, may offer some good sentiment to airlines company, thus respite as long as major oil producers sell their products at loss-making prices.

The recent drop in WTI oil prices should allow the national airlines to maximize their planes' fuel for about half the price it cost when two months ago. If not for COVID-19, the national airlines would be collecting huge profits since fuel is the highest operational cost for an airline. However, the COVID-19 has led national airlines to take advantage as a small win in during the suffering losses. Besides, the other detail that airlines can appreciate is the fact that COVID-19 is not likely to lead to long-term restructuring, unlike the terrorist 9/11 (Hadden, 2020). Aside from small changes to fleets and re-route networks due to early aircraft retirement and the loss of profitability of some tracks, the operational plans for airlines likely to remain unchanged. These conditions are different from the $9 / 11$ terrorist attack, in which many airlines removed hubs from their route networks, canceled routes, and reevaluated their expansion plans. The COVID-19 Pandemic may leave the airline industry's impact from a growing passenger standpoint, but from a logistical perspective, good things will come or more the same.

Even as airlines are in a dreadful situation on pastpandemic, they still effort best and making some preparations for when passengers return to the skies. However, there's a still long way before they can operate at full scale as a couple additional activities and rules by transport ministry will add to their difficulties in order to obey physical distance measurement such as: 1) Revenue lost from blocked off middle seats to prevent close contact with each passenger; 2) The cost of protective gloves and masks or PPE wore by the cabin crew will add more cost regularly; 3) Regular and precise airplane cabin cleaning with disinfectants; 4) Redesign the ground ticketing and luggage counter with glass partitions.

The problem that major airline companies will be facing after this pandemic is whether they should leave planes on the ground and pay a huge amount of money or sent them to other markets. Both decisions are hard; tackling a few planes is expensive since the companies will have to continue paying the rents for airplanes, especially for Garuda Indonesia, with more than 60 percent is rented planes. Increasing the plane capacity can indeed lead to lower ticket prices, but during the past-outbreak always complicated to reverse that, with the protocol to obeying the physical distance measurement.

Moreover from this study, we conclude some findings that the bankruptcy prediction using modified Altman Z-score shows that all selected airlines are predicted to be distressed or bankrupt in the next two and three years in the future. Mostly the Garuda Indonesia and Thai Airways have already been in financial distress since the beginning of 2018, and impact of COVID-19 worsens the financial condition on those company. This study aims to raise awareness for the non-manufacturers company, especially airlines, that there are several things to be focused on and to be well-controlled. Based on this analysis, Working Capital and EBIT influence most of the bankruptcy events in all periods in every company. Thus, the expenses or operational costs are the most significant issues in Airlines Company included, fuel cost, labor, and airplane equipment. 
Thus the company should carefully allocate remaining assets, and liquidate the unproductive entities and subordinates units.

\section{Managerial Implications}

From our study, it was also found that Garuda Indonesia was predicted to go bankrupt for a long time, but it has not been declared bankrupt until now. This condition can be said to be the bad side of BUMN. The Indonesian government will continue to maintain its national pride, with the help of considerable funds to prevent the company from going bankrupt. Hence, the government's role is also essential so that Garuda Indonesia can survive and be able to withstand these difficulties. At the history of JAL (Japan Airlines), which was declared bankrupt in 2008, but with close cooperation between airline management and the Japanese government, JAL can avoid bankruptcy. Therefore, Garuda Indonesia management should conduct a revenue management strategy and scenario planning to compete in the airline industry and overcome bankruptcy without getting the Indonesian government's bailout fund.

The aviation industry will continue to suffer significantly from COVID-19, but things will eventually get better. It's hard to predict how long it will take for the situation to improve because this global pandemic situation is the first in our generation. In the short term, the airline industry may start to recover after a few months. However, it could take several months or even longer for some parts of the industry to improve in the long term. The reality of this situation is that Garuda Indonesia will continue to go bankrupt soon. Where workers are forced out of their jobs, numerous flights will continue to be canceled, and travel plans will continue to be postponed. The future of Garuda Indonesia is now dependent on business leaders, Indonesian governments, and, most importantly the passengers itself.

\section{CONCLUSIONS AND RECOMMENDATIONS}

\section{Conclusions}

In our study, we conclude that the COVID-19 caused significant economic impact worldwide, further it will also have broader implications on the airline industry. The shutdown of several parts of its commercial activities, with consequences for air and road transport people movement and global business activity, reduces the need for airlines worldwide. For the regional airlines industry, the spread of the outbreak in East Asian spill over all around the world, would having a disastrous impact on tourism-based air traffic, representing the majority of the tourist tour package are postponed until COVID-19 could be controlled in destination countries. Likewise the slowdown in air-transport caused by the spread of the COVID-19 epidemic is leading many international companies to reduce their flight programs and put in place savings measures and substitute with online meetings.

This bankruptcy prediction results show that all the current issues and aviation outlook on airline industry performance are partly right. There is a bad financial performance inside the rapid revenue growth of the Airlines Company. However, several companies are predicted to be bankrupt from a long time ago, like Garuda Indonesia and Thai Airways, that not declared bankrupt until now. These conditions are bad sides of state-owned enterprises, which the government of Indonesia or Thailand will do whenever it takes to survive its national pride, with huge financial aids to prevent this company from bankruptcy. Other than that, these close to-failure national airlines, also supported by many different things, included non-financial factors, such as the main air transportation for federal and government civil workers.

Moreover, this bankruptcy prediction analysis can be beneficial for investors, corporations, and Indonesian governance to improve the company's performance. Furthermore, from this study we can conclude that COVID-19 is not the leading cause of its bad financial performance. Despite the ability of Altman formulas to predict the bankruptcy event, it should be noted that all of these scores are just a prediction. In the postpandemic to come, national airlines should be on stand-by mode and rush to be the first that could flight and secure as many customers as possible. In order to stay effective and competitive, Garuda Indonesia should operate smarter. They will need to restore some health concern and goodwill to loyal passengers. And most importantly, from a profit standpoint, they need to lower overhead and maximize reliability. In order to stay competitive, Garuda Indonesia should not afford to have broken aircraft sitting in hangars and getting repaired with no profit margins. 


\section{Recommendations}

Those findings contribute to the research on the pandemic's bankruptcy analysis. Since there is no other study-related national carriers analyze the impact on outbreak yet, while this paper is being written, thus this study slightly provides another reference for the business financial distress when pandemic occurred. Moreover, this study has several limitations that only examine financial ratios using the Altman z-score model that could not look deeper inside the operational of the business itself.

\section{REFERENCES}

Adnan H, Arisudhana D. 2011. Analisis kebangkrutan model Altman Z-Score dan Springate pada perusahaan industri property. Jurnal Akuntansi dan Keuangan 1(1): 89-110.

AlSabah A, AlAli M, Alshamali M, Alawadhi K. 2018. The use of Zmijewski Model in Examining the Financial Soundness of Oil and Gas Companies Listed at Kuwait Stock Exchange 1: 15-21.

Altman EI. 1968. Financial ratios, discriminant analysis and the prediction of corporate bankruptcy. The Journal of Finance 23(4): 589-609. https://doi. org/10.1111/j.1540-6261.1968.tb00843.x.

Altman EI, Peck M. 1995. Emerging market corporate bonds: A scoring system. Emerging Market Reviews $6: 311-323$.

Altman EI. 2000. Predicting financial distress of companies: revisiting the Z-Score and Zeta Models. Journal of Finance and Journal of Banking \& Finance 26-27.

Altman EI. 2005. An emerging credit scoring system for corporate bonds. Emerging Market Review 6 (5): 311-323. https://doi.org/10.1016/j. ememar.2005.09.007.

Altman E, Hotchkiss E. 2005. Corporate Financial Distress and Bankruptcy. Hoboken: Wiley. https://doi.org/10.1002/9781118267806.

Anjum S. 2012. Business bankruptcy predicting models: The Altman's Z-score models. Asian Journal of Management Research 3(1): 3-8.

Archana HN. 2018. Default prediction using altman z score model - a study of some select retail firms. Sumedha Journal of Management 7(4):60-75. https://doi.org/10.5958/23220449.2018.00006.6.

Auchterlonie D. 1997. A Paean to the Z-Score and Its commercial bankruptcy prediction. The Journal of Lending \& Credit Risk Management 80(1).

Aviation Outlook. 2018. Airline Industry Outlook: 2018 - AviationOutlook. [online]

Balcaen S, Hubert O. 2006. 35 Years of Studies on Business Failure: An Overview of the Classic Statistical Methodologies. The British Accounting Review 38(1): 63-93. https://doi. org/10.1016/j.bar.2005.09.001.

Bellovary J, Giacomino D, Akers M. 2007. A review of bankruptcy prediction studies: 1930 to present. Journal of Financial Education 33: 1-42.

CAPA - Centre for Aviation. 2018. Southeast Asia Aviation 2018 Outlook.

CNA. 2019. Singapore Airlines swings to $\mathrm{S} \$ 138 \mathrm{~m}$ net loss in Q4. Available at https://www. channelnewsasia.com/news/singapore/ singapore-airlinesswings- to-s-138m-net-lossin- q4-8861432 [Accessed 23 May 2019].

Carter, David A, Betty JS. 2004. The market's reaction to unexpected: the case of airline stock returns and the 9/11 attacks. The Quarterly Review of Economics and Finance 44(4):539-558 https:// doi.org/10.1016/j.qref.2003.10.001.

Chava S, Jarrow RA. 2004. Bankruptcy prediction with industry effects. Social Science Research Network 8(4): 537-569. https://doi.org/10.1007/ s10679-004-6279-6.

Chen, Ming-Hsiang, Woo Gon Kim. 2007. The impact of the SARS Pandemic on Taiwanese Hotel stock performance: an event-study approach. The International Journal of Hospitality Management 26 (1): 200-212. https://doi. org/10.1016/j.ijhm.2005.11.004.

Dimitras AI, Zanakis SH, Zopounidis C. 1996. A survey of business failures with an emphasis on prediction methods and industrial applications. The European Journal of Operational Research 90(3): 487-513. https://doi.org/10.1016/03772217(95)00070-4.

Duan, Hongbo, Shouyang Wang, and Cuihong Yang. 2020. Coronavirus: limit short-term economic damage. Nature 578 (7796): 515. https://doi. org/10.1038/d41586-020-00522-6.

Fakoano V, Achsani NA, Maulana T NA. 2018. Kinerja keuangan perusahaan properti menggunakan metode Zmijewski. Jurnal Aplikasi Bisnis Dan Manajemen (JABM) 4(3): 341. https://doi. org/10.17358/jabm.4.3.341

Garcia AA, Sayago A, González G. 2006. The Correlation Coefficient: An Overview. 
Grice JS, Ingram RW. 2001. Tests of the generalizability of Altman's bankruptcy prediction model. Journal of Business Research 54 (1): 53-61. https://doi.org/10.1016/S0148-2963(00)001260 .

Hanafi M, Halim, A. 2007. Analisis Laporan Keuangan. Yogyakarta: Unit Penerbit dan Percetakan Sekolah Tinggi Ilmu Manajemen YKPN.

IATA. 2019. IATA Forecast predicts 8.2 billion Air travelers in 037. Availableat:https://www.iata. org/pressroom/pr [Accessed 23 May 2019].

Khan A. 2014. How does stock prices respond to various macroeconomic factors? A case study of Pakistan. Journal of Management Info 4(1): 7595. https://doi.org/10.31580/jmi.v4i1.22.

Kollias C, Apostolos S. 2011. Stock Markets and Terrorist Attacks: Comparative evidence from a large and a small capitalization market. The European Journal of Political Economy 27 (S1): S64-S77. https://doi.org/10.1016/j. ejpoleco.2011.05.002.

Kuncoro AW. 2012. Analisis Kebangkrutan dengan Metode Springate dan Zmijewski pada PT Betonjaya Manunggal Tbk Periode 2007- 2011. Jakarta: Universitas Budi Luhur.

Kumar M, Anand M. 2013. Assessing financial health of a firm using Altman's original and revised Z-Score Models: a case of Kingfisher Airlines Ltd (India). Journal of Applied Management and Investments 2: 36-48.

Manalu S, Octavianus R, Kalmadara G. 2017. Financial distress analysis with Altman Z-Score Approach and Zmijewski X-Score on shipping service company. Jurnal Aplikasi Manajemen 15: 677682. 10.21776/Ub.Jam.2017.015.04.15.

Mansi SA, Maxwell WF, Zhang A. 2010. Bankruptcy prediction model and the cost of debt. Journal of Fixed Income, Forthcoming, https://doi. org/10.3905/jfi.2012.21.4.025.

McCabe RM. 1998. Why airlines succeed or fail: A system dynamics synthesis. Available from ProQuest Dissertations \& Theses Global: The Sciences and Engineering Collection. (304429819).

Mordor Intelligence .2018. Asia-Pacific Aviation Market - Growth, Trends, and Forecast (2019 2024). www.mordorintelligence.com/industryreports/ [Accessed 23 May 2019].

Muslich M. 2007. Modern Financial Management Analysis, Planning, and Policy. 4th ed. Jakarta: PT. Bumi Aksara.

Panneerselvam R. 2008. Research Methodology. New Delhi: Prentice Hall of India Private Limited.

Peter Y. 2011. Bankruptcy analysis with method of Z-Score Altman, Springate, and Zmijewski at PT Indofood Sukses Makmur Tbk for the Period of 2005-2009. Akurat Jurnal Ilmiah Akuntansi 2(4).

Schofield A. 2018. Garuda Indonesia reports 2017 loss as fuel inflates cost. reports-2017-loss-fuelinflates-cost.

Sedgwick P. 2012. Pearson's correlation coefficient. BMJ 345: e4483-e4483. https://doi.org/10.1136/ bmj.e4483. 